\title{
The crude protein production of grassland and the utilization by milking cows
}

\author{
A. Kemp, O. J. Hemkes and T. van Steenbergen \\ Centre for Agrobiological Research (CABO), Wageningen, the Netherlands
}

Accepted: 11 August 1978

Key words: protein excess, grass, cows

\section{Summary}

In this paper an attempt is made with experimental data of various origin to quantify the intake of nitrogen from pasture grass by milking cows during the grazing period. It is also demonstrated how much of this nitrogen is removed by secretion in the milk as well as the concentrations of nitrogen in the faeces and in the urine remaining on the pasture after grazing. From a fertilizer application to the pasture of $450 \mathrm{~kg} \mathrm{~N}$ per ha per year an equal concentration is taken up by the herbage. Of this herbage nitrogen about $75-80 \%$ remains on the pasture after grazing. The concentrations remaining on the grassland increase sharply with rising nitrogen doses and this goes parallel with an increasing intensity in the nitrogen circulation in the system soil - plant - animal - soil and a rising nitrate content in the surface layer of ground water.

\section{Introduction}

Especially due to the much higher nitrogen fertilizer applications to grassland, grass production was considerably increased in the course of years. Some 25 years ago nitrogen fertilizer application to grassland was some $50 \mathrm{~kg}$ of pure $\mathrm{N}$ per ha in the Netherlands, whereas this is upwards of $200 \mathrm{~kg}$ nowadays. In addition the much higher imports of feeds during the same period, especially for pig and poultry, caused the nitrogen in the organic manure to rise appreciably as well. Jagtenberg (1975) calculated, on the basis of a detailed study on the grassland production of farm fields during many years, that only as a result of the increased fertilizer nitrogen the average dry matter production of grassland increased by some $40 \%$ in the last 25 years, to an average production of some $11000 \mathrm{~kg}$ per ha per year. Alberda's work (1968) showed that under optimum growing conditions this production can be further increased.

Not only the dry matter production, but especially the crude protein yield of grassland is considerably increased by the use of more nitrogen. From data of van 


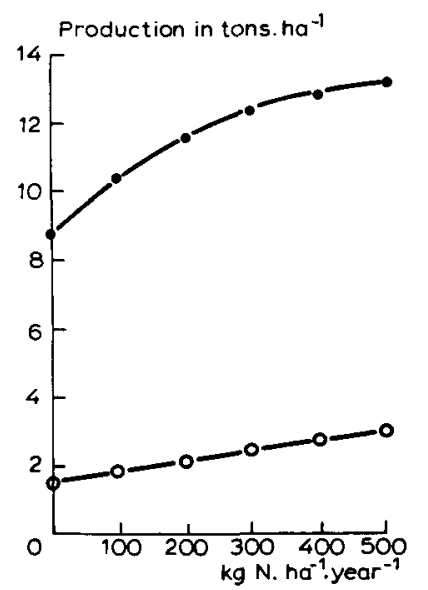

Fig. 1. Annual production of dry matter and crude protein of permanent grassland with diverging doses of fertilizer $\mathbf{N}$ (. - . . . dry matter, o-o-o crude protein)

Steenbergen (1977), Fig. 1 shows that the line indicating the relation between nitrogen application and dry matter production will sooner show a deflection at higher dressings, due to diminishing returns, than the line showing the relation between fertilizer nitrogen and crude protein yield. Especially in this deflecting range the herbage will contain more crude protein at higher $\mathrm{N}$ dressings, when harvested at the same length.

It is estimated that in the Netherlands about two thirds of the total grass production is utilized by grazing, especially with milking cows. Also by the increased supply of concentrates in the pasture the number of milking cows per ha as well as the milk production per cow have increased in the course of the years. In grassland exploitation the aim is to have always sufficient young and energy rich pasture grass available during the grazing period in order to meet the energetic requirement of the milking cows in so far as possible with pasture grass. This is realized by nitrogen fertilizer dressings and the application of good grazing techniques. Due to these measures, however, the consumption of crude protein by the grazing animals has increased more sharply than its requirement for maintenance and milk production. With the rising nitrogen application the surplus of crude protein with respect to its requirement has also continued to increase.

This paper is intended to give a quantitative idea of the crude protein consumed by grazing milking cows at diverging nitrogen fertilizer applications related to the requirement of crude protein at various milk yields. At the same time the secretion of nitrogen in the milk is dealt with as well as the excretion of nitrogen in the faeces and in the urine remaining on the land.

\section{Data used}

The data on the trend in the contents of crude protein in the herbage during the season have been taken from the work of de Boer and van Steenbergen who during ten years (1964-1973) collected data on the annual herbage production on 24 ex- 
perimental fields, which were set out on the most representative old grassland types in the Netherlands. Each experimental field included the treatments 0, 100, 200, 300,400 and $500 \mathrm{~kg}$ fertilizer $\mathrm{N}$ per ha per year, in which the nitrogen was distributed in different doses during the growing season. To determine the herbage yield, each year another already pretreated plot in the same field was selected, to avoid as much as possible the effect of frequently cutting. On these experimental fields the first cut of all the treatments was harvested at a dry matter yield of about $4000 \mathrm{~kg}$ per ha and therefore on different dates. The second and third cuts of all the treatments were harvested when the dry matter yield was estimated to be about 1500 to $2000 \mathrm{~kg}$ per ha, the same applies to the fifth and possibly the sixth cuts. The fourth cuts of the treatments 0,100 , and $200 \mathrm{~kg} \mathrm{~N}$ were also harvested at this yield level, but those of the treatments 300,400 and $500 \mathrm{~kg} \mathrm{~N}$ were cut at yields of 2500 to $3000 \mathrm{~kg}$ of dry matter per ha. The percentage distribution of the total amount of nitrogen applied in the successive cuts for the treatments 100 and $200 \mathrm{~kg} \mathrm{~N}$ was 40 , 25,20 and $15 \%$ and for the treatments with over $200 \mathrm{~kg} \mathrm{~N}$ roughly $40,20,15,20$ and $5 \%$. The crude protein contents in the herbage of the first and the fourth cuts mentioned in this paper were corrected with the aid of data from other experimental fields to herbage contents at a yield level of about 1500 to $2000 \mathrm{~kg}$ dry matter per ha.

For more detailed data on the lay-out of the experimental fields, determination of the yield and sampling, readers are referred to de Boer (1966) and van Steenbergen (1977).

In the course of the years rather many data were collected in the Netherlands in grazing experiments on the amount of herbage consumed by grazing cows. A generally accepted disadvantage of these observations is that the error in the estimated dry matter intake by cattle is relatively great. Using all the available data H. Wieling (pers. commun., 1976) estimated as well as possible the dry matter intake of milking cows calved down approximately 1 February, during the growing season. This estimation has been used for the calculations in this paper.

Data on the digestibility of the crude protein by milking cows and on the secretion of nitrogen in the milk and the excretion in the faeces and in the urine were taken from a great number of balance trials with milking cows fed on fresh herbage. For a detailed description of these experiments carried out during 1958-1966, readers are referred to Kemp et al. (1960).

\section{The intake and requirement of crude protein}

The intake of crude protein from grassland herbage by grazing cows is determined by the amount of dry matter consumed and the crude protein content of it. Fig. 2 was composed from the data of de Boer \& van Steenbergen and shows the average trend in crude protein contents during the growing season at applications of 100 , 300 and $500 \mathrm{~kg} \mathrm{~N}$ per ha per year on clay, peat and sandy soil. It stands to reason, that the contents may vary considerably from field to field and from year to year. Within the scope of this paper, however, it was not considered necessary to deal further with this question.

In early spring the herbage with a fertilizer application of $100 \mathrm{~kg} \mathrm{~N}$ per year 

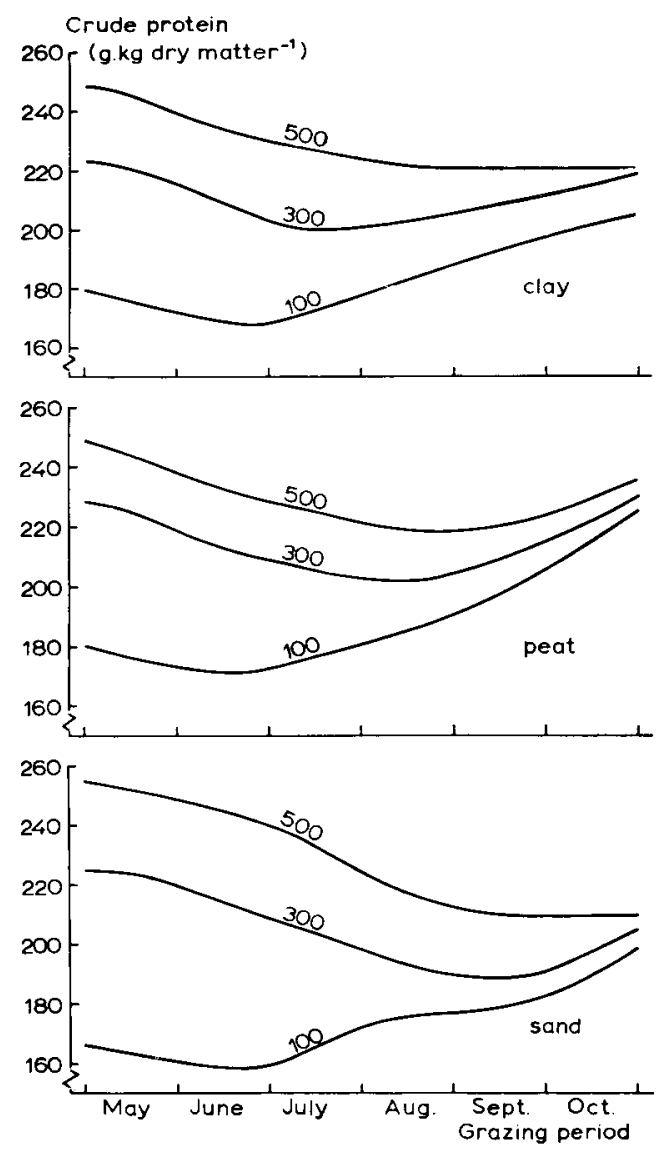

Fig. 2. Trend in the crude protein contents of the herbage during the grazing period at diverging doses of nitrogen.

contains on an average 17 to $18 \%$ of crude protein, whereas this content amounts to some $25 \%$ on the treatment $500 \mathrm{~kg} \mathrm{~N}$ per year. Up to half June these contents decrease on all three soil types with the low as well as with the high doses of $\mathrm{N}$ fertilizer. This decrease continues longer as more $\mathrm{N}$ fertilizer is applied. In the treatment of $100 \mathrm{~kg} \mathrm{~N}$ per growing season this decrease in the contents changed at the end of June or beginning of July into an increase. With $500 \mathrm{~kg} \mathrm{~N}$ this decrease continues until roughly the end of August or beginning of September. Only on the peat soils the contents will rise again afterwards, whereas on the clay and sandy soils they remain constant at this nitrogen level. On the fields fertilized with $100 \mathrm{~kg}$ $\mathrm{N}$ the herbage contained considerably more crude protein at the end of the growing period than in spring, whereas the herbage on the fields with $500 \mathrm{~kg}$ nitrogen showed the reverse effect. This is evident especially on sandy soils and might be related to less mineralized soil nitrogen being available to the herbage in spring than later in the season, which effect will be more distinct on the crude protein content of the herbage on the treatments with a low dose of nitrogen. The differences in the crude protein contents of the grass on the plots fertilized lightly and heavily with nitrogen 
are therefore small in autumn compared to those differences in spring. Attention is called to the fact, however, that the differences in nitrogen application between the treatments in autumn were much smaller than in spring.

The trend in the crude protein contents during the season were determined with data from experimental fields that were cut throughout a growing season. This might have affected the trend in the contents as shown in Fig. 2. However, a comparison of these data with those obtained from experimental fields that were grazed throughout a season did not indicate that exclusively cutting will actually change the level or the trend in the contents ( $\mathrm{Tj}$. Boxem, pers commun., 1976).

From the mentioned estimation by Wieling Fig. 3 was composed, showing the average dry-matter intake of milking cows calved down in spring, with a milk production of 4000,5000 and $6000 \mathrm{~kg}$ milk per annum. Roughly, the intake of a milking cow with a production of $6000 \mathrm{~kg}$ per year should be upwards $20 \%$ higher than that of one with a production of $4000 \mathrm{~kg}$ milk per year. During the lactation period the dry matter intake is supposed to decrease some $15 \%$.

From the data on the trend in the contents of crude protein in the herbage in Fig. 2 and from the dry matter intake of the cows in Fig. 3 the daily crude protein intakes by the animals were calculated. Fig. 4 shows these data at various nitrogen doses and at diverse milk yields by dashed lines. Because of the small differences in the crude protein contents of the herbage on clay soil and on peat soil these data were taken together.

It is evident that the crude protein intake per animal per day sharply decreases during the grazing period when the grassland is fertilized with doses of 300 or $500 \mathrm{~kg}$ of $\mathrm{N}$. This is due to the decreasing intake of dry matter by the animals as well as to the decreasing crude protein contents in the grass. With a dose of $100 \mathrm{~kg}$ nitrogen the crude protein contents of the herbage rise in the first two months of the grazing season to such an extent that, despite a decreasing dry matter intake, the crude

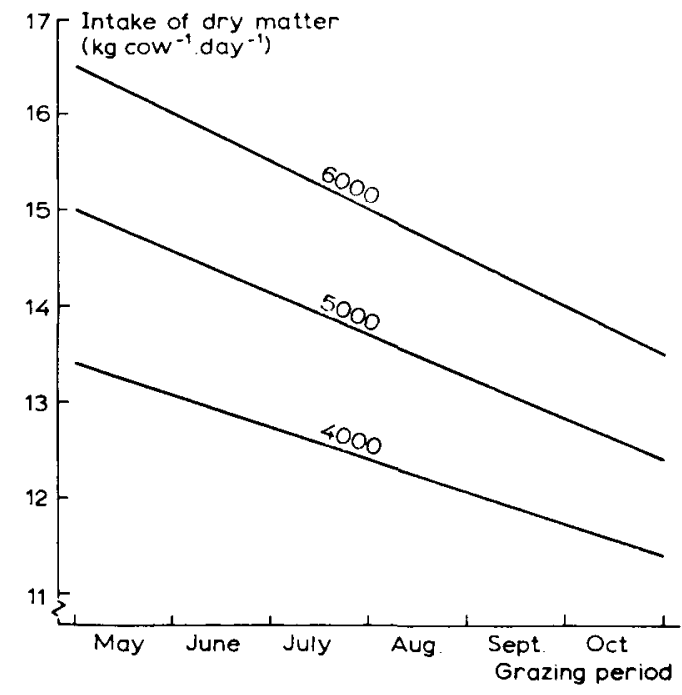

40
Fig. 3. Dry matter intake by grazing milking cows with different milk yields. 
clay and peat
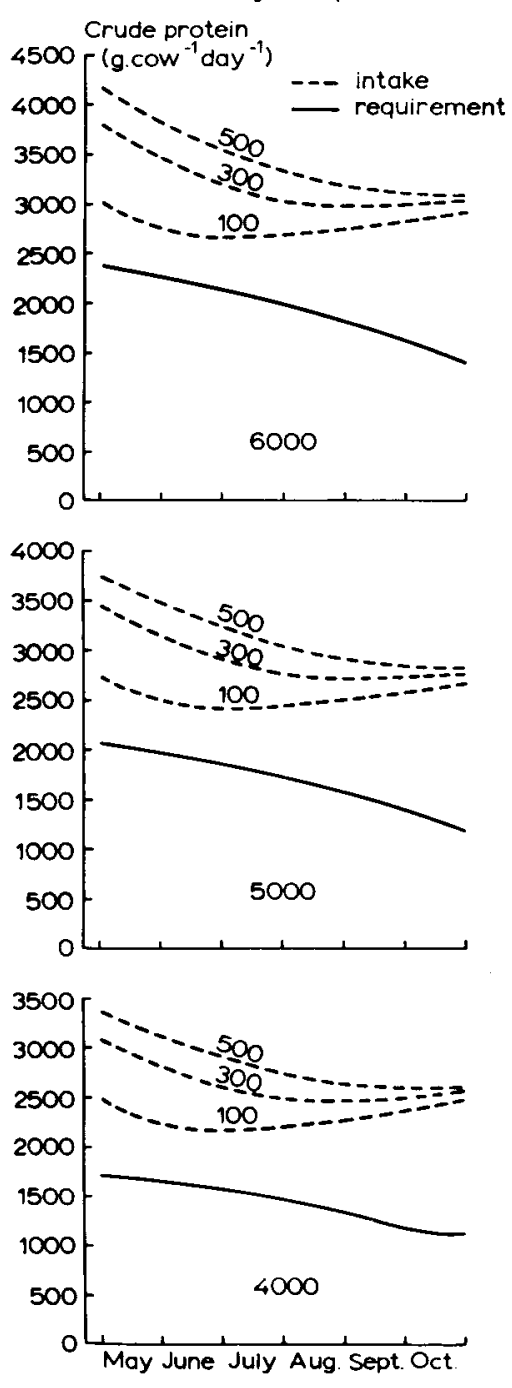

sand
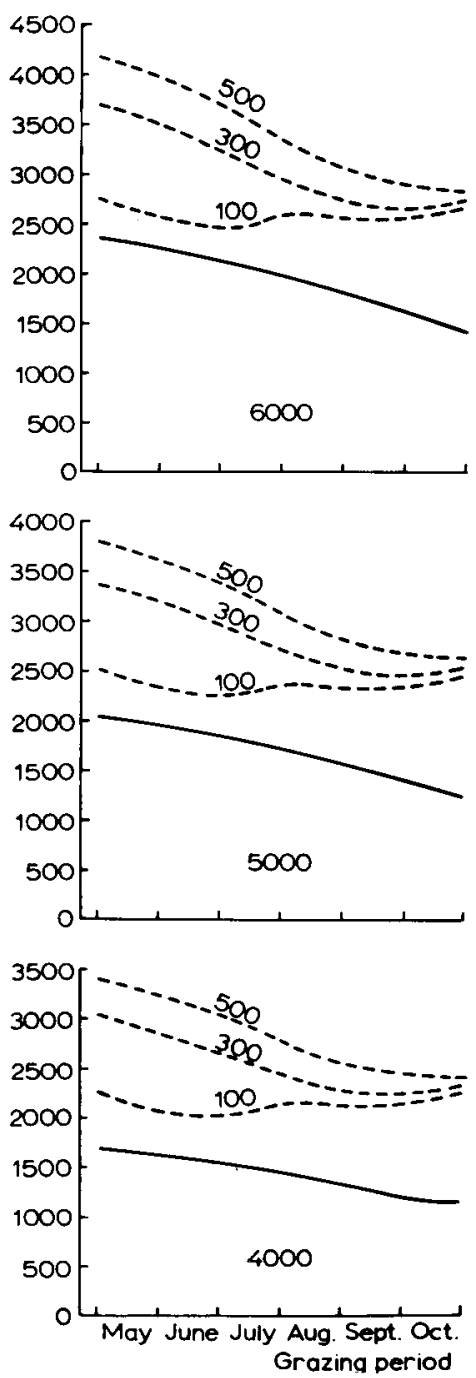

Fig. 4. Comparison of the crude protein requirement with the crude protein supply for cows with different milk yields and with various nitrogen applications to the pasture.

protein intake by the animals after an initial decrease, begins to rise again. This results in a crude protein intake by the animals that is about as high at the end of the grazing season than it was at the beginning. The highest intakes amount to more than $4000 \mathrm{~g}$ of crude protein per cow per day and occur on the fields with a high nitrogen dose at the beginning of the grazing period. The lowest intakes are about half of this and occur on the fields with a low dose of nitrogen, at the beginning of summer. 
The solid lines in Fig. 4 show the daily requirement of crude protein of milking cows calving down in spring at yields of 4000,5000 and $6000 \mathrm{~kg}$ of milk per cow per year. The trend in these yields during the lactation period was calculated after the method of Doeksen and Heyboer (1952) and is presented in Fig. 5. For the daily yields to be inferred from this figure the relevant daily requirements of crude protein were taken from the feeding standards used in the Netherlands. These requirements were expressed in Fig. 4 in crude protein with the data mentioned earlier on the digestibility of crude protein in fresh herbage by milking cows.

Since the digestibility of crude protein increases at higher contents in the herbage - and accordingly in this study at higher nitrogen applications - with protein rich grass less crude protein is needed to meet the requirement than when the protein content in the herbage is low. Thus at the nitrogen levels of 100,300 and $500 \mathrm{~kg}$ as in Fig. 4, separate lines for the requirement of crude protein could be given. As the differences are, however, rather small, we sufficed by drawing in this figure only one line for the requirement of crude protein, i.e. that which holds for herbage with crude protein contents attained at doses of $300 \mathrm{~kg} \mathrm{~N}$ per ha per year.

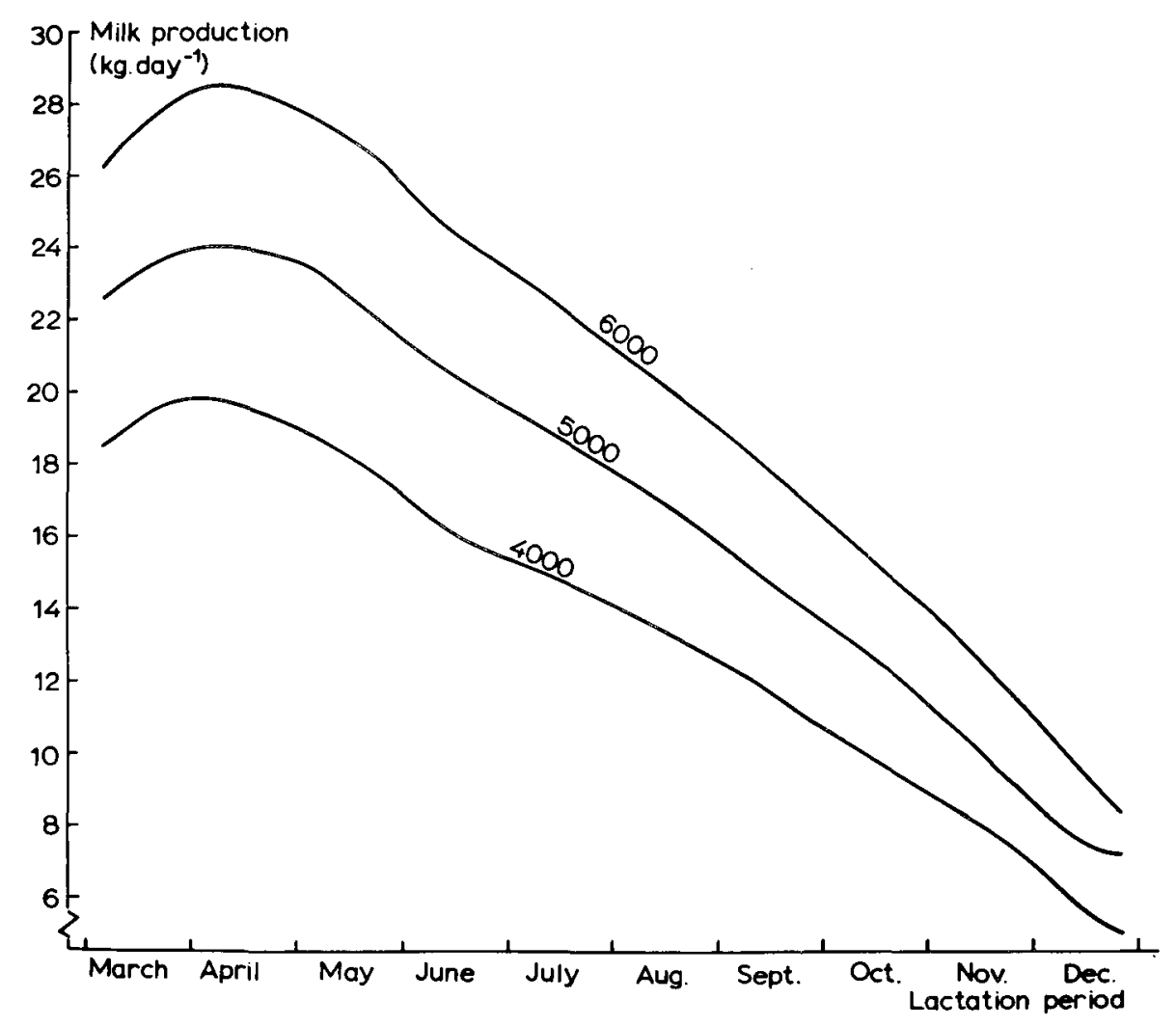

Fig. 5. Lactation curves of milking cows with different annual productions. 


\section{Excess of crude protein and grazing losses}

When comparing the daily intakes of crude protein, as mentioned in Fig. 4 at the various nitrogen levels with the daily requirement of it by milking cows, it is found that throughout the grazing period the crude protein intake is by far in excess of its requirement. On the fields with a high dose of nitrogen on clay and peat soils the crude protein excess in spring and in autumn is about equal and amounts to roughly $1500 \mathrm{~g}$ per cow per day. On sandy soil this is in spring of about the same size as on clay and peat soils, but in autumn it is somewhat lower. On the clay and peat soils the surplus in summer is somewhat lower than in spring and autumn. On the fields with a low dose of nitrogen on all the soil types the excess in autumn is over two times as high as in spring, which is about 1000 and $500 \mathrm{~g}$ per cow per day, respectively. This appreciable difference between spring and autumn is caused by the rising crude protein contents in the herbage during the season and a simultaneously occurring decrease in the requirement of protein by the animals, due to a lower milk yield. With an average dose of some $200 \mathrm{~kg} \mathrm{~N}$ per ha, as is usual in the Netherlands nowadays, the excess of crude protein will average some $1000 \mathrm{~g}$ per animal per day throughout the growing season.

In the preceding the utilization of crude protein was in question after the animals had consumed the herbage. However, when considering the utilization of the nitrogen fraction in a standing crop to be grazed, attention will have to be paid to the losses occurring during grazing. Grazing losses are mainly caused by treading and contamination of the grass during grazing, they are, among others, dependent on the grazing system, the length of the herbage when putting the cows to pasture, the soil conditions, the carrying capacity of the sward and the weather conditions. Grazing experiments have demonstrated that these losses can be limited to some $10 \%$, when a strip grazing system is applied. In this system the cattle are put to pasture on a short grass sward with a good carrying capacity and under conditions that are not wet. Under a very extensive grazing system in long herbage and under wet conditions, the losses due to treading and contamination may rise to over $30 \%$.

Fig. 6 shows a recapitulation of the total fraction of non-utilized protein, caused by the protein in excess of that required for maintenance and milk production and by grazing losses. This calculation was carried out for grazing losses of $15 \%$ and of $30 \%$. The length of the columns in Fig. 6 indicates the supply of herbage crude protein per animal per grazing period of 180 days and at a dry matter intake given in Fig. 3. This total protein supply is divided into three parts, i.e. the crude protein necessary for maintenance and milk yield, that consumed in excess and the top part indicating the grazing losses of crude protein with a good and with a less good grazing system. Thus, this figure shows that on sandy soil with a nitrogen dose of $300 \mathrm{~kg}$ per ha per year for a cow with a milk yield of $5000 \mathrm{~kg}$ per year and with grazing losses of $30 \%$, the total supply of herbage crude protein will be about $700 \mathrm{~kg}$ during the grazing season. About $40 \%$ of this is needed to meet the requirements, whereas almost $60 \%$ is not utilized as a protein source, due to excess and grazing losses. The crude protein excess, as already mentioned, increases appreciably with higher nitrogen dosages. Roughly it amounts to $100 \mathrm{~kg}$ of crude protein 

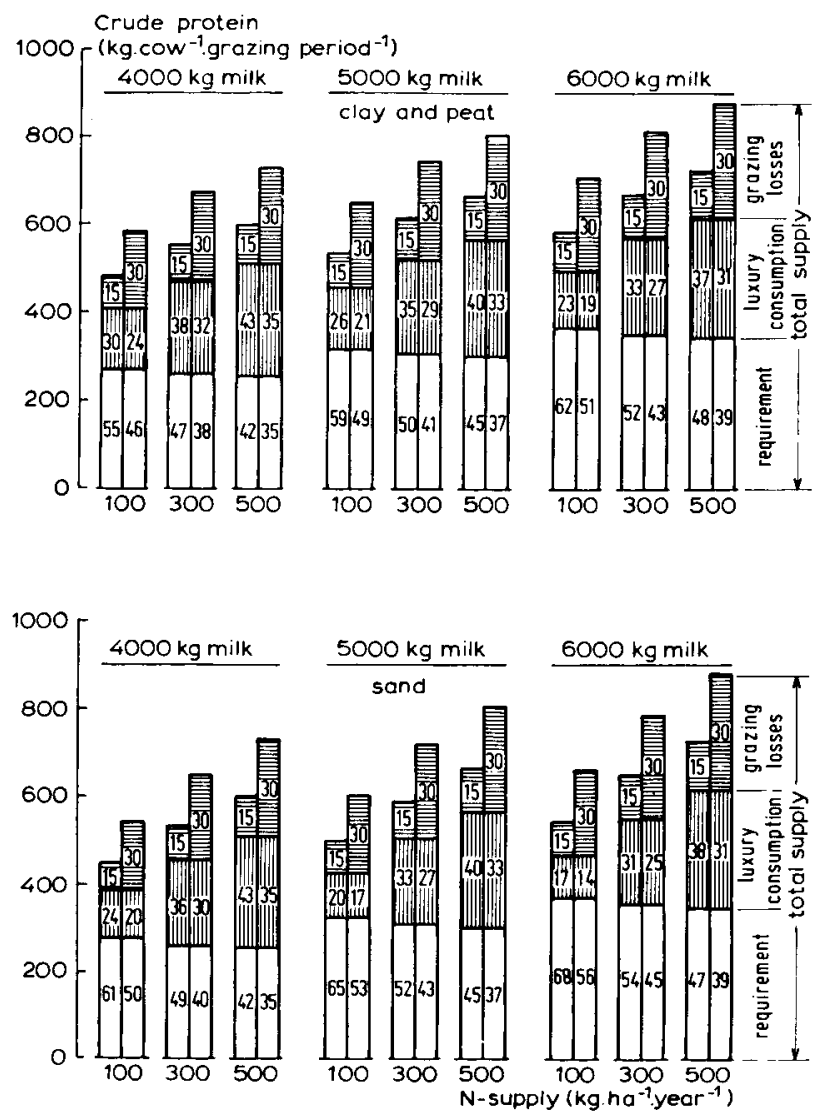

Fig. 6. Estimations of the requirement, excess consumption and grazing losses of crude protein at various levels of $\mathrm{N}$ application.

per cow per grazing season with a light $\mathrm{N}$ supply and some $250 \mathrm{~kg}$ with a dose of $500 \mathrm{~kg} \mathrm{~N}$ per grazing period. The effect of a rising milk yield on the excess is only small compared to that of an $\mathrm{N}$ application.

Secretion of nitrogen in the milk and excretion in the faeces and in the urine during grazing

At the same bodyweight of grazing dairy cows the nitrogen secreted in the milk is the only nitrogen removed during pasturing not taking into account the losses from volatilization, run-off and leaching.

After a light $\mathbf{N}$ dose and consequently a low intake of crude protein by the animals - about $25-30 \%$ of the nitrogen consumed with the herbage is removed with the milk. The remaining part is excreted in the faeces and in the urine, which 
can be inferred from Fig. 7. This figure also shows that with high and very high doses of nitrogen, the part secreted in the milk decreases to $15-20 \%$. This means that $85-80 \%$ of the consumed nitrogen is returned to the pasture in the faeces and in the urine.

To find the total amount of nitrogen remaining on the pasture after grazing, the part of the nitrogen present in the herbage that is not consumed by the animals, because of grazing losses, should be added. These losses, as mentioned before, may amount from 10 to $30 \%$ of the nitrogen present in the herbage. Van Steenbergen (1977) concluded from the data on his experiments, already mentioned, that with a dose of $400-500 \mathrm{~kg}$ fertilizer $\mathrm{N}$ per ha per year, the nitrogen uptake by the herbage was about $450 \mathrm{~kg} \mathrm{~N}$. When no $\mathrm{N}$ fertilizer is applied the amount taken up by the herbage is ca. $225 \mathrm{~kg} \mathrm{~N}$ per ha.

Of the nitrogen taken up by the herbage at high nitrogen levels about $380 \mathrm{~kg} \mathrm{~N}$ remains on the grassland as grazing losses (in this case these have been put at $20 \%$ of the nitrogen present in the herbage) and as excretion in the faeces and in the urine ( $80 \%$ of the nitrogen consumed). When no nitrogen is applied these percentages can be put at 20 and $70 \%$, respectively, in this case about $170 \mathrm{~kg} \mathrm{~N}$ per ha of the nitrogen taken up by the herbage is returned to the pasture during grazing. Roughly it can be stated that with very divergent nitrogen doses after grazing with milking cows, $75-80 \%$ of the nitrogen present in the grass remains on the pasture. The increase in the intensity of the nitrogen circulation and of the nitrogen losses in the system soil - plant - animal - soil, as a consequence of the yield increase of pastures by means of nitrogen, has thus been clearly demonstrated. In this relation the work of Steenvoorden \& Oosterom (1977) is also interesting. They found a

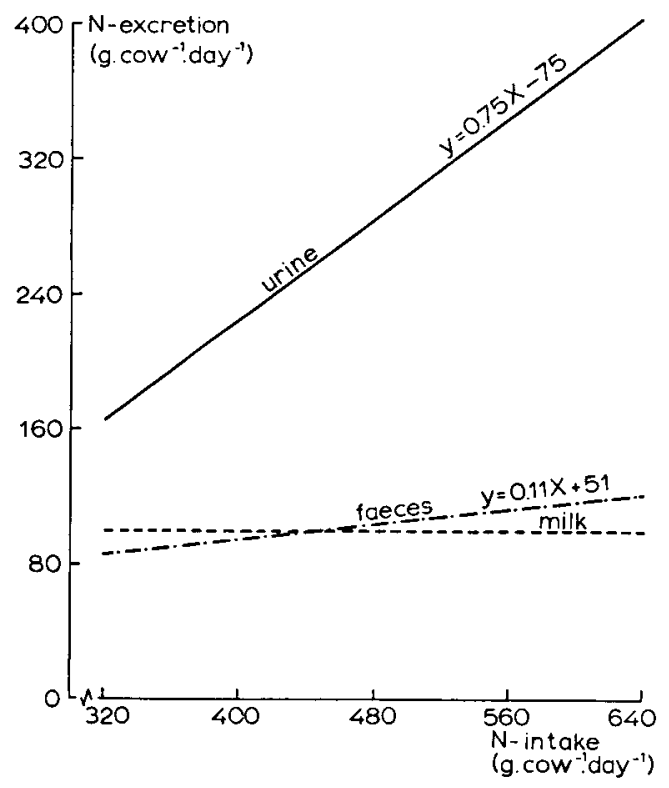

Fig. 7. Nitrogen intake with pasture grass and its excretion in the milk, in the faeces and in the urine by milking cows with a daily production of $20 \mathrm{~kg}$ of milk. 


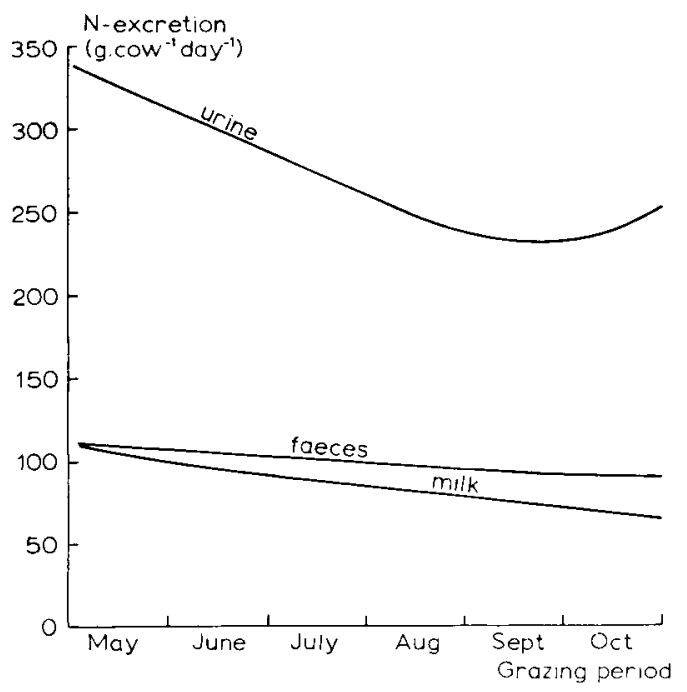

Fig. 8. Nitrogen excretion in the milk, in the faeces and in the urine by milking cows during the pasturing period.

positive relation on sandy soil between nitrogen application and the nitrate contents of the top layer of ground water.

The nitrogen consumed by the animals in excess of that required for maintenance and production is mainly excreted in the urine. Fig. 7 shows the relation between nitrogen intake with the fresh herbage and the excretion in the faeces and in the urine. For comparison also the nitrogen secretion in the milk has been mentioned at a daily yield of $20 \mathrm{~kg}$ of milk. This figure was composed from data on the earlier mentioned balance trials - digestion trials with milking cows fed on fresh herbage.

With a low nitrogen intake, too low to meet the requirement for maintenance and milk yield, nitrogen excretion in the urine is almost two times as high as that in the milk and in the faeces. The total excretion in this case is higher than the intake and the balance is therefore negative. A higher nitrogen intake will increase the excretion in the faeces. The slope of this line is determined, on the one hand, by the higher nitrogen intake, and on the other hand, by changes in the apparent digestibility coefficient of the consumed nitrogen, i.e. that part of the nitrogen consumed not excreted in the faeces. In the material studied the digestibility coefficient of crude protein increases from upwards $70 \%$ to about $80 \%$ with increasing intakes, because with a high intake of nitrogen relatively younger and more digestible material was supplied to the animals and therefore less nitrogen was excreted in the faeces. At the same digestibility of the crude protein the slope of the line should have been steeper.

The excretion of nitrogen in the urine increases sharply with higher intakes. With a consumption of $640 \mathrm{~g}$ per animal per day about $400 \mathrm{~g}$ is excreted in the urine. At this level of intake this is about three times as much as in the faeces.

The distribution of nitrogen secreted in the milk, in the faeces and in the urine during a grazing season is, of course, very different. Fig. 8 shows the trend in a cow, calving down in spring, with an annual yield of $5000 \mathrm{~kg}$ of milk, fed on grass only, 
fertilized with $300 \mathrm{~kg} \mathrm{~N} \mathrm{ha}^{-1}$. The secretion of nitrogen in the milk grows lower as the growing period continues, because the milk yield decreases from spring to autumn. The lower nitrogen excretion in the faeces is caused by the lower feed intake and by a decreasing protein content in the grass. The excretion of nitrogen in the urine at the beginning of the grazing period is almost $350 \mathrm{~g}$ per day. This is more than three times as much as in the faeces or in the milk. Because of the lower dry matter intake and the lower crude protein content of it, the excretion of nitrogen in the urine is reduced to a level of some $230 \mathrm{~g}$ per day in September. Afterwards there is another small increase due to a sharp rise in the protein content of the herbage.

Possibly the excretion of nitrogen or nitrogenous substances is a matter of interest in relation to the occurrence or not of scorched patches in the pasture after the release of urine by grazing cattle. Under grazing conditions the amount of urine produced mainly depends on the water intake (dry or wet herbage) and of the potassium intake. As to the latter aspect: because of the diuretic activity of potassium, there is a rather close positive relation between the potassium intake and the amount of urine produced. In this case it could be expected that on fields with herbage rich in potassium these scorched patches will occur less rapidly than on fields with low potassium herbage. During pasturing it may be expected that the concentration of nitrogen in the urine during the first two to three months will be appreciably higher than in late summer and autumn. For, the total concentration of nitrogen excreted in the urine will be highest during the first months of pasturing, whereas the intake of water with respect to its requirement for milk production will be the highest during the last months of pasturing.

\section{References}

Alberda, Th., 1968. Maximale grasproduktie. Landbouwplantenteelt: 135-149.

Boer, Th. A. de, 1966. Nitrogen effect on the herbage production of grasslands on different sites. Proc. 10th int. Grassld. Congr. (Helsinki) 199-204.

Doeksen, J. \& D. C. Heyboer, 1952. Het omrekenen van melkvee tot standaardkoeien. Versl. landbouwk. Onderz. 58. 7.

Jagtenberg, W. D., 1975. Verhoging van de graslandproduktie noodzakelijk en mogelijk. Bedrijfsontwikkeling 6: 413-417.

Kemp, A., W. B. Deijs, O. J. Hemkes \& A. J. H. van Es, 1961. Hypomagnesaemia in milking cows: intake and utilization of magnesium from herbage by lactating cows. Neth. J. agric. Sci. 9 (2) 134-149.

Steenbergen, T. van, 1977. Invloed van grondsoort en jaar op het effect van stikstofbemesting op de graslandopbrengst. Stikstof 85: 9-15.

Steenvoorden, J. H. A. M. \& H. P. Oosterom, 1977. De chemische samenstelling van het ondiepe grondwater bij rundveehouderijbedrijven. ICW, Wageningen, Nota 964. 